\title{
The Good, The Bad, The Ugly \& The Futile: The Memory \& Their Impact On Human Beings
}

\author{
Richa Sharma, Saurabh Raj \\ Assistant Professor, Department of \\ Applied Science and Humanities \\ Ganeshi Lal Bajaj Institute of \\ Technology and Management \\ Greater Noida, India \\ \{richa.sharma, saurabh.raj\}@glbitm.ac.in
}

\author{
Vibhuti Sharma \\ Assistant Professor, \\ Department of Management \\ Ganeshi Lal Bajaj \\ Institute of Management \\ Greater Noida, India \\ vibhuti.b20@gmail.com
}

\begin{abstract}
The smriti or the memory is the vital part of our mental body. In fact, it is essential for every unit (in human \& animal order) in existence. Here the authors are specific to the human order. Memory, specifically to the mental body has been categorized in many ways in the literature. Here the authors are classifying the memory in a novel way based on the analysis done of the existing classification. Further the strength $\&$ limitations of memory are also discussed. Memory can also be seen as the boundary or the limitation. The same concept has been described over here. Memory causes vrittis (others being vikalpa or verbal delusions, viparyaya or false knowledge, nidra or sleep, swapn or dreams) which create opacity for the mind stuff or chitt visibility and hence hurdle in the path of self actualisation. Vrittis in the literature has been described as the form the mind takes upon encountering above-mentioned ripples. This can be further viewed as an anti-force restricting the human order to propagate towards cosmic (higher level) identity. Location of the memory storage and the time period before rehearsal also determines the nature of the memory. Based on this the authors have proposed to categorize the memory as volatile \& non-volatile.
\end{abstract}

Index Terms-Manas, mental body, chitt, vritti, memory, smriti, volatile, eustress, distress, cosmic identity.

\section{INTRODUCTION}

If you are not changing your mind (thinking/manas) nothing will change.

If you change your mind (thinking/ manas) everything will change.

Anonymous

\footnotetext{
$\mathrm{A}$ CCORDING to the Yogic philosophy the mental body(manas) has been divided into four parts. Intellect (buddhi), identity(ahankara), memory(smriti) \& mind stuff (pure intelligence or chitt). The intellect when associated with the memory becomes intelligence and intelligence without memory is the mind stuff or pure intelligence or chitt. Ancient Indian philosophy has largely described the importance of manas equally to the physical body. Charak \& Sushruta has described the seating of mind in the heart whereas there are references indicating the seating of mind in
}

the whole physical body. If we refer to the electromagnetic field present all around our body we find different aura as prana or physical aura, psychological aura, psychical aura \& projected aura. Thus the second layer or the psychological aura may be said to represent the mental power and activities [7]. There are references indicating up to seven layers. They are physical, sacral, emotional, astral, spiritual, intuitional and absolute layers. Most of these layers are in some or other way linked to the mental powers and activities. Every cell in the human body (of course applicable to the animal order as well) is a type of micro mental body hence carries one or other kind of memory. Let us first explore the literature and clarify the concepts related to this.

\section{Literature Review}

Manas has been defined as Uhayatmaka Indriya which means both sensory organs and action organs. We can call it as antahkarana. Manas is described as the mind in Ayurveda. There are many references indicating the seat of manas or mind in the heart or hridaya. There is evidence indicating the seat of manas as the whole body [20]. Literature defines manas as a link between atma (soul) and sharir (body). Manas is primarily inactive and gets activated when combined with atma (soul). Memory is one of the elements of manas $[1,16]$.

Every human being has got only one indivisible mana. It is neither a force or energy nor any matter. It is an attribute or part of the self. It is no way linked to the soul and not immortal $[11,23]$. The word manas has been derived from the Sanskrit root word which means 'to know'. Yajurveda describes manas as an inner flame of knowledge which regulates all senses. Thus there is literary evidence which indicates the duality of manas. They call manas a sense as well as a motor. So when manas is associated with the senses the one of the outcome is memory [4].

As per the Yoga philosophy citta or the mind or pure intelligence when encountered by any type of vritti is the manas [8]. Let us have an analogy with the computational 
system which will make the things clearer. The computer or a laptop is like a self or 'I'. Operating system software is like mind or manas and an integral part of the self. Without manas(OS) self(device) is useless as well as cannot exist without the hardware(body). The electricity is like consciousness required to run the hardware(body). Consciousness and manas are two separate things like an interface between manas and self. Thus when electricity(consciousness) is linked to the hardware(body) operating system software is loaded and makes the device(self) operatable. The functions of manas(OS) like learning, emotions, memory ceases with shutdown of the device (self) [23]

The vaisheshika philosophy says that the interaction of atma(soul), indriya(organ) and manas(mind) results in realisation of happiness, unhappiness, dreams, memory (smriti) etc $[2,10,13]$. Manas joins atma, senses to evolve the emotions like attachment, aversion, fear, anger which are the major cause of vrittis and hence the smriti or memory [3].

Mind stuff or citta is said to be the combination of manas, buddhi, ahankara and senses. Mind and consciousness are two separate things. They need not to be confused with each other. Mind is simply the instrument of perception and experience. As the vrittis are being generated, may be due to vikalpa, viparyaya, smriti, dreams or susupti (dreamless sleep) self enjoys or suffer accordingly [12].

The Upanishads have also described manas in their own ways. Amartanandopanisad says Mind is the major cause of both bondage $\&$ liberation. The mind is a subtle matter with an outcome in the form of the memory as a source of feelings and emotions. Kenopnisad says that mind and intellect can move together spreading over all sensory organs (in a way the entire body). Kathopnishad says the senses are like the horses of a chariot (body) in which the charioteer is the buddhi. To control the horse's mind is the motor organ regulated by the soul. In Prasnopanisad the mind is said to be active when it desires, thinks \& expects. Having dreams in the sleep indicates memory in a form is causing a disturbance wave. Mandukyopanisad tells us the four stages of consciousness namely wakeful or jagrat, swapn or dream, susupti or deep sleep \& turiya or super consciousness. Panchkosas doctrine says manas is the organ of perception, memory \& understanding which give rise to mind. (The concept of mind in major upnishads, no author, no date)

Jain philosophy opines that the constituent atoms making manas are active and there are four possible forms a manas can take up. These are true or pure, deceptive, combination of true and deceptive \& combination of untrue and deceptive. Mati or senses and sruta or the source of knowledge are termed as indirect or paroksha sources of cognition whereas clairvoyance, telepathy and omniscience are the direct or pratyaksh sources. In Sankhya philosophy cognition through senses is a process that involves buddhi, ahankara, manas and indriyas or senses. Whatever be the source of the cognition one of the outcomes is smriti or memory [21].
Patanjali has identified basic mental functions as pramana or valid knowledge, viparyaya or illusion, vikalpa or imagination, nidra or sleep \& smriti or memory [5].

\section{Sharirendriyasatvaatmasanyog dhari jivitam}

This means that manas (mind), atma (soul) and sharir (body) together lead to a healthy life of an individual $[9,17,18]$.

The functions of manas has been described as manovyapar by Charakacharya which is as under

\section{Atindriyam punarmana satvasangyakam chet ityahureke, tadarthamasampattadayattachestam chestapratyabhumindriyaanaam}

This means that the knowledge acquired or not acquired depends on manas which is certainly an interface between senses and soul. Buddhi or the intellect has three sets dhi, dhruti and smriti. Smriti recollects the status of the information newly perceived $[9,17,18]$. If we explore the relevant ancient literature, manas is supposed to be situated in the heart, head or mastulung. Few scholars agree that manas is located in the entire body $[9,17,18]$.

The literature talks of four layers of human aura namely physical aura, psychological aura, psychical aura and the projected aura. The physical aura surrounding the body immediately can be sensed easily. Next to follow is the psychological aura which represents a person's mind. Psychical aura is next to follow which in turn is enveloped by the projected aura. This simple configuration of auras represents the spread of mind (manas) all over the body in form of psychological / psychical / projected auras [6, 7].

Western philosophical tradition creates an ontological distinction of physical or physiological or biological body and the mental body. The mental body comprises soul, intellect, mind, emotions etc. Nearly all the western thinkers have supported the idea of mind-body dualism. In the western philosophy the concept of mind is something different. They talk of the wandering spirits or shamanism which is capable of walking into and outside the body. Later Homer identified these spirits as souls which were supposed to be located in the head. He gave the concept of two types of soul body soul and impersonal immortal soul capable of ethereal travel. Later Plato came up with the concept of a single soul for a person, however it consisted of three parts namely thymos, logos and pathos. Logos which means logical reasoning is attributed as the mind which is supposedly immortal. Aristotle, a disciple of Plato, has described three types of soul, rational (thinking \& analysing), sensitive (passions \& desires) and nutritive (appetite \& drives). According to him, the mind was simply an attribute of the self. Few things are to be made clear regarding the concept of manas [11.23].

Dictionaries define aura as "Any subtle, invisible emanation or exhalation.". [22] Prana aura represents the energy or force which makes the soul manifest and in turn the mind manifests the thought activity [22]. Every human being is surrounded by some electromagnetic radiation or energies. 
This is now detectable. This energy surrounding the person or released by the person is called aura. Kirlian photography is a contact print process and has no camera or lens supporting the existence of aura spread all over the body [6].

Memory as perceived can be categorized in three as working memory, short term memory and long term memory. Working \& short term memory lie in the prefrontal cortex of our brain where as long term memory is located in the portion called hippocampus. All memories are supposed to be in array form. Working memory (through gyanendriya) after many rehearsals get into prefrontal cortex as short lived memory. Similarly, short lived memory (in the prefrontal cortex) after many rehearsals get into the hippocampus as long lived memory [15].

A volatile memory is a memory which tends to be erased after a time gap if not rehearsed properly. It can be treated like RAM in the case of a computer. Whatever information is stored there vanishes if not committed or saved or the system shuts down abruptly. Long term memory can be termed as non-volatile memory just like ROM in case of a computer [14].

\section{Proposed Work}

Here in this paper the author recognises the importance of memory $\&$ the significant impact on human beings. Authors are widely analysing the impact accepting it as one of the causes of happiness / suffering. Another cause is the imagination.

\section{The Concept}

The above discussion makes few things clear to us:

1. Consciousness is an energy or force that drives our soul (atma) and mind(manas).

2. The interaction of soul(atma), mind(manas) and organs (both sensory and action) results in feelings, emotions and memory. Here we are going to focus on memory.

3. Majority of things in our life do not result in short or long term memory. They may be termed as volatile memory. The probable reason being its non-rehearsal.

4. Short term and long term memory happens probably due to limited or even unlimited number of rehearsals and the impact they have on the subject.

Now we propose a memory classification as good memories, bad memories, ugly memories and futile memories.

Good memories are the happenings we cherish and may love if the event occurs again. For example, getting a prestigious award, some sort of reunion with old acquaintances etc.

Bad memories, on the other hand, creates a feeling of sadness, agony in us and we wish to erase them as soon as possible and pray for its non-occurrence. They cause a feeling of distress in us. For example, losing someone near and dear to you, any ghastly emergency like an ambush attack or terrorist activity etc.

Ugly memories are the memories that teach us something. Like getting a reward after properly completing a task. Initially we wish for its non-recurrence but later we realise the things and get better prepared. This can be a potential source of stress.

Futile memories mean useless for us. Occupying the space unnecessarily and we wish to erase them as they can be causing vrittis thought waves disturbances.

\section{Analysis: Memory Model}

The memory can have a positive as well as negative impact on us, hence we develop a model exhibiting the same.

Table 1:Positive and Negative Impact on Memory

\begin{tabular}{|l|c|c|}
\hline & Positive Impact & Negative Impact \\
\hline Good & Yes & ---- \\
\hline Bad & ---- & Yes \\
\hline Ugly & May be & May be \\
\hline Futile & Low Chances & Low Chances \\
\hline
\end{tabular}

The matrix above deals with possible impact on human beings of various types of memory.

Good memories are always cherished and have a positive impact on us. Conversely bad memories have a negative impact on us and we try to get rid of them. Ugly memories are associated with us in a mixed way. They normally teach us a lesson \& we may or may not welcome the recurrence. Futile memories are like scrap /garbage kept in our house to be thrown out. They may not find any use for us.

\section{Conclusion \& Future scope of WORK}

The memory is the outcome of the interactive process between the components of the physical, mental and spiritual body of a human being. A good touch/word/action and a bad touch/word/action propagates a message through the sensory / motor organs and lies in our prefrontal cortex or hippocampus as a good or bad memory. Similarly, we can have ugly memories which are disliked by most of us as we are not realising it anyway. Lastly we have futile memory which is like junk mail occupying space in our mailbox. We are indifferent to it.

The memory is a potential source of creating thought waves in us which in turn disturb our mental health and perhaps holistic health. Future endeavours can be devising a tool / technique (physical/mental/spiritual) to get rid of such memories at least. If we are able to do so, that will be a great 
foot for the entire mankind and we can ensure a smooth movement towards cosmic identity [19].

\section{REFERENCES}

[1] Acharya Y.T. (2006) Charak Samhita with Ayurveda [Online] Available at: https://www.bibliomed.org/fulltextpdf.php?mno=170946 (Accessed : 10 August 2021)

[2] Amin,Hetal \& Sharma, Rohit (2014). Concepts of Manas (mind): An Insight from Vaiseshika Darshana and Ayurveda, British Journal of Medical and Health Research,1(1), pp. 1-12.

[3] Amin,Hetal \& Sharma, Rohit (2016). Concept of Manas in Mimāṃsā Darśana, Yog-Mimansa,48(1), pp. 4-8

[4] Amin, H, Sharma, R, Vyas, H A, \& Vyas, M K (2015). Concept of Manas in Samkhya Darshana, Indian Journal of History of Science, 50 (1), pp. 125-130, DOI: 10.16943/ijhs/2015/v50i1/48115.

[5] Amin, H, Sharma, R, Vyas, H A, \& Vyas, M K (2014). Importance of Manas Tattva: A searchlight in Yoga Darshana, 35(3): 221-226 PMCID: PMC4649565.

[6] Chabbra, G, Naraynan, A, \& Samantha, S (2013). Human Aura: A New Vedic Approach in IT, International Conference on Mechanical and Industrial Engineering, 26th May-2013, New Delhi, ISBN: 97893-82208-95-2

[7] Charles T. Tart (1972). Concerning The Scientific Study of the Human Aura, Journal of the Society for Psychical Research, 1972, 46, No. 751, 1-21. Copyright 1972 Charles T. Tart

[8] Das, B C (2018). The Concept of Citta in Yoga Philosophy, Philosophy and the Life-world, Vol.20, pp. 46-54, ISSN: 0975-8461.

[9] Flood, Gavin (2021). The Concept of Mind in Hindu Tantrism, The Journal of Hindu Studies, pp.1-32, doi:10.1093/jhs/hiaa020.

[10] Harold T, Smith M, Nolan R. Living issues in Philosophy, 9th edition, Belmont: Wadsworth Pub. Co.
[11] IGNOU: School of Social Sciences (2015). Fundamentals of Mental Health: Concept of mind, Indira Gandhi National Open University, pp. 14-26, ISBN-978-81-266-6715-4

[12] Krishnappa, D T, Sridhar, M K, \& Nagendra, H R (2020). Concept of mind in Indian philosophy, Western philosophy, and psychology, Yog-Mimansa, 52(1), pp. 25-28

[13] Maharshi Kanada (1924). Vaiseshika Darshana, V.D. 5/2/14,16, Swami Darshananand Saraswati, Shankaradatta Sharma, Moradabad, 1924:76.

[14] Micron Technology. What is the Difference Between RAM and ROM? Available at : www.micron.com (Accessed : 17 August 2021).

[15] Miller, Allanah, (2021). Three types of memory important to learning: working, short-term, and long-term memory, Available at : thriveworks.com (Accessed : 13 August 2021).

[16] Pathak, Madhu, Sharma, Anita \& Kumawat, D K (2017). Role of Ancient Indian Sciences in Mental Health, World Journal of Pharmaceutical Research, 6, No. 7, pp. 534-543, ISSN 2277-7105, SJIF 7.523.

[17] Taylor, S (1890). A Case of "Intellectual Aura " OR " Dreamy State, The Lancet, pp. 276-277,

[18] Sharma P.V., Sushrut Samhita (2005). Sushrut Samhita with Nibandha Samgraha, Commentary of Dalhana, Eighth edition, Varanasi (india), Chaukhambha Orientalia, 2005; 375

[19] Sharma, R \& Raj, S (2021). Cosmic Identity, Turkish online journal of qualitative inquiry, 12(9), pp. 178-185.

[20] Shivgotra, Rachin \& Gupta, Rahul Kumar (2019). Literary review of Manas in Ayurveda, Journal of Ayurveda and Medical Sciences, 2019, 4(2), pp 118-120, ISSN 2456-3110.

[21] Soni, Jayandra (2020). The Concept of Manas in Jaina Philosophy, Journal of Indian Philosophy 48: pp. 315-328.

[22] Swami Panchadasi, (no date) The Human Aura Astral Colours and Thought Forms, Yog publication society.

[23] Thirunavukarasu, T (2011). A utilitarian concept of manas and mental health, Indian Journal of Psychiatry,53(2), pp. 99-110, doi: $10.4103 / 0019-5545.82532$. 